\title{
Analisa Perbandingan Kinerja Panel Surya Vertikal dengan Panel Surya Fleksibel pada Jenis Monocrystalline
}

\author{
Budiyanto ${ }^{1}$, Hery Setiawan ${ }^{2}$ \\ 1,2) Teknik Elektro Universitas Muhammadiyah Jakarta \\ e-mail : yan.budiyanto@yahoo.com ${ }^{1}$, herysetiawan95@gmail.com ${ }^{2}$
}

\begin{abstract}
ABSTRAK
Besarnya daya keluaran yang dihasilkan relatif tidak konstan karena dipengaruhi oleh besarnya intensitas matahari serta suhu lingkungan di sekitarnya. Efisiensi lebih tinggi dibanding dengan panel surya vertikal, yaitu 20,8774\%, sedangkan panel surya vertikal meghasilkan efisiensi sebesar 19,2844\%. Dalam penggunaan simulasi pencahayaan lampu panel surya vertikal menghasilkan efisiensi yang cukup tinggi dan lebih tinggi dibanding panel surya fleksibel, yaitu $20,4818 \%$ sedangkan panel surya fleksibel menghasilkan efisiensi sebesar 16,4044\%. Pada panel surya fleksibel dengan bentuk cembung $25^{\circ}$ menghasilkan efisiensi sebesar 15,3200. Pada bentuk cekung $25^{\circ}$ menghasilkan efisiensi $15,6265 \%$.
\end{abstract}

\section{ABSTRACT}

The main problem with solar cells is the different types of solar cells that cause differences in the performance of the solar cell. The amount of output power generated is relatively not constant because it is influenced by the intensity of the sun and the temperature of the surrounding environment. To solve this problem, this final project is designed to compare the vertical and flexible types of monocrystalline solar panels. In the test results with solar lighting, flexible solar panels produce higher efficiency compared to vertical solar panels, namely $20.8774 \%$, while vertical solar panels resulting in an efficiency of $19.2844 \%$. In the use of simulated lighting, vertical solar panel lights produce high and higher efficiency than flexible solar panels, namely $20.4818 \%$, while flexible solar panels produce an efficiency of $16.4044 \%$. In a flexible solar panel with a $25^{\circ}$ convex shape, the efficiency is 15.3200 . At $25^{\circ}$ concave form the efficiency is $15.6265 \%$.

\section{Kata Kunci : Panel Surya, Panel Surya Vertikal, Panel Surya Fleksibel, Efisien}

\section{PENDAHULUAN}

Listrik sangat penting bagi kehidupan orang banyak [1]. Penggunaan sumber daya alam yang tidak dapat diperbaharui sudah mulai mengkhawatirkan [2]. Berkurangnya ketersediaan energi fosil menyebabkan dunia mulai beralih ke penggunaan energi alternatif [3]. Mengurangi ketebalan wafer silikon kristal telah menjadi tujuan jangka panjang dalam industri tenaga surya [4]. Panel Surya adalah alat konversi energi cahaya matahari menjadi energi listrik [5]. Fotovoltaik seluler (PV) adalah sebuah teknologi yang dapat memenuhi kebutuhan ini dengan memanfaatkan ruang fleksibel yang muncul teknologi fotovoltaik [6]. Fotovoltaik fleksibel film tipis membuka jalan menuju listrik berbiaya rendah [7]. Sel surya polimer dapat diolah dari solusi atau dispersi yang menawarkan sangat penting potensi teknologi untuk fabrikasi berbiaya rendah ke area yang luas dan substrat fleksibel [8]. Matahari adalah sebuah bola panas dari gas yang dipanaskan oleh reaksi fusi nuklir [9]. Indonesia merupakan negara yang terletak di garis khatulistiwa yang mempunyai tingkat radiasi harian matahari rata - rata yang relatif tinggi yaitu 4,5
$\mathrm{kWh} / \mathrm{m}^{2} /$ hari. Hal tersebut dapat digunakan sebagai modal utama pembangkitan listrik dengan menggunakan solar cell. Daya yang dihasilkan oleh solar cell berbanding lurus dengan besarnya intensitas matahari yang diterima panel surya. Semakin besar intensitas matahari yang diterima oleh panel maka semakin besar daya yang dapat dihasilkan oleh solar cell tersebut [10]. Besarnya intensitas matahari yang diterima oleh panel surya dipengaruhi oleh beberapa faktor seperti letak astronomi lokasi pemasangan panel, gerak semu harian dan tahunan matahari serta cuaca. Permasalahan utama dari solar cell adalah perbedaan jenis solar cell yang mengakibatkan perbedaan kinerja pada solar cell tersebut. Besarnya daya keluaran yang dihasilkan relatif tidak konstan karena dipengaruhi oleh besarnya intensitas matahari serta suhu lingkungan di sekitarnya. Pada kondisi standarnya sistem solar cell yang mempunyai efisiensi sebesar $10 \%$ - $30 \%$ dapat menghasilkan daya sebesar 100 - 300 Watt pada saat intensitas matahari yang diterima sebesar $1.000 \mathrm{~W} / \mathrm{m} 2$ dan pada suhu sebesar $30^{\circ} \mathrm{C}$. Dengan adanya perbedaan jenis solar cell ini yang melandasi untuk merancang 
RESISTOR (Elektronika Kendali Telekomunikasi Tenaga Listrik Komputer) Vol. 4 No. 1 e-ISSN : 2621-9700, p-ISSN : 2654-2684

dan meneliti penelitian ini. Dari latar belakang diatas maka didapat rumuskan masalah bagaimana membuat perancanaan dan perancangan sistem yang dapat digunakan untuk melakuan perbandingan diantara panel surya fleksibel dan panel surya vertikal. Dalam penelitian ini terfokus pada permasalahan yang terjadi, maka ruang lingkup penelitian ini dibatasi pada:

1. Jenis panel surya yang digunakan merupakan panel surya fleksibel dan vertiakal jenis monocrystalline.

2. Daya panel surya yang digunakan sebesar $10 \mathrm{Wp}$ untuk untuk panel surya fleksibel dan panel surya vertikal.

3. Penggunaan Aki atau baterai sebagai media penyimpan energi listrik.

4. Pengontrollan output dari solar panel surya ke battery dan output dari panel surya ke beban menggunakan Solar Charge Controller.

5. Penyinaran cahaya menggunakan panas matahari dengan cara penyinaran langsung.

6. Penilitian ini difokuskan pada efisiensi solar cell, arus $(\mathrm{A})$, tegangan $(\mathrm{V})$, intensitas cahaya $\left(\mathrm{W} / \mathrm{m}^{2}\right)$, Daya $(\mathrm{P})$, pada saat penyinaran langsung. Adapun tujuan dari penelitian ini adalah :

1. Dapat membandingkan kinerja panel surya fleksibel dengan panel surya vertikal pada jenis monocrystalline.

2. Dapat diketahui hasil perngukuran dari hasil perbandingan pada panel surya fleksibel dan panel surya vertikal jenis monocrystalline.

3. Dapat mengetahui karakteristik panel surya fleksibel dan panel surya vertikal pada jenis monocrystalline.

Istilah photovoltaic diturunkan dengan menggabungkan kata Yunani untuk cahaya, foto, dengan volta, dinamai Alessandro Volta. Sel surya adalah suatu alat yang mngubah energi matahari menjadi energi listrik secara langsung. Sel surya terbuat dari batu polucristal silium yang dihancurkan menjadi sebuk silium dan kemudain dipadatkan menjadi bentuk batang dan setelah itu dipotong menjadi lembaran setebal $0.3 \mathrm{~mm}$. Sel surya dalam keadaan tanpa penyinaran memiliki prinsip kerja seperti dioda. Setelah sel surya mendapat sinar matahari sampai dengan ke permukaan N-S, maka energi akan diserap. Energi ini yang biasa disebut photon. Kemudain, energi tersebut akan bertabrakan denngan silikon bermuatan negatif dan positif, akibat dari tumbukan ini akan menimbulkan energi panas pada sel surya.

\section{METODOLOGI}

Pada penelitian ini merencanakan dan merancang rangkaian penelitian yang dapat

digunakan untuk membandingkan panel surya vertikal dan fleksibel. Dalam penelitian ini terdapat beberapa rangkaian pengujian untuk mendapatkan hasil yang maksimal.

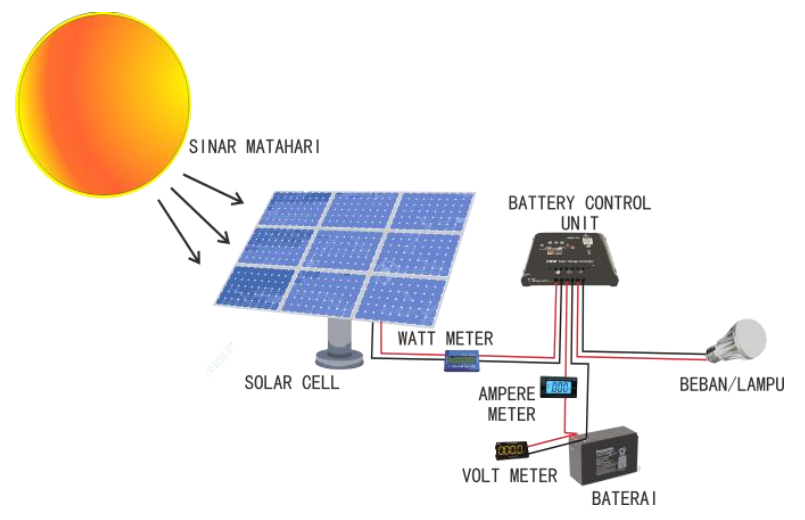

Gambar 1 Rangkaian pengujian panel surya vertikal dengan pencahayaan matahari.

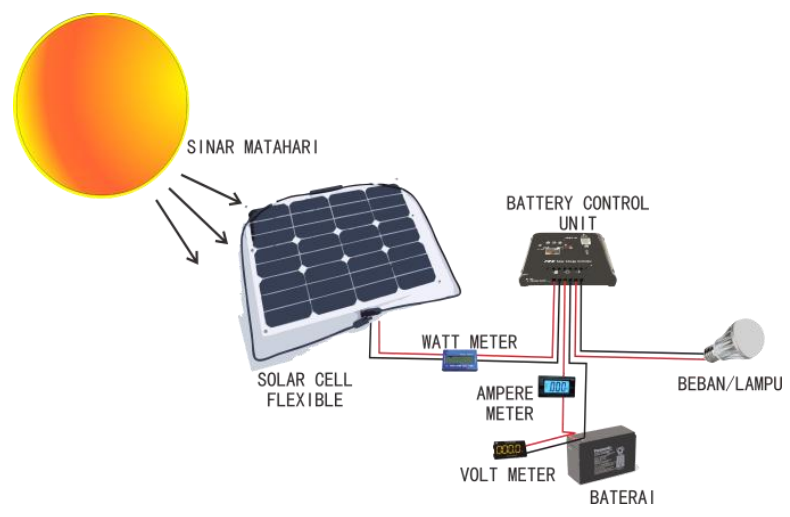

Gambar 2 Rangkaian pengujian panel surya fleksibel dengan pencahayaan matahari.

Tidak hanya dengan matahari, penelitian ini juga menggunakan simulasi pencahayaan lampu dengan menggunakan lampu halogen $8 \times 50 \mathrm{~W} / 220 \mathrm{~V}$.

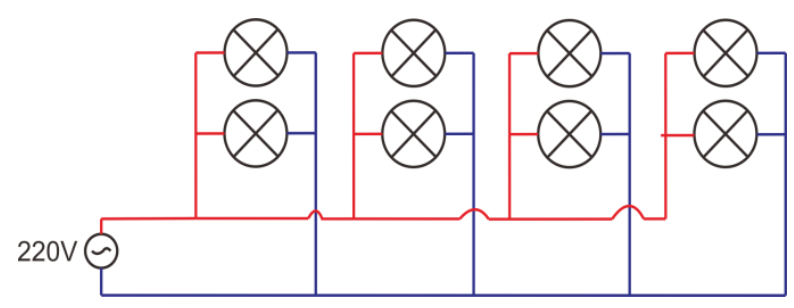

Gambar 3 Rangkaian simulasi pencahayaan lampu. 
RESISTOR (Elektronika Kendali Telekomunikasi Tenaga Listrik Komputer) Vol. 4 No. 1 e-ISSN : 2621-9700, p-ISSN : 2654-2684

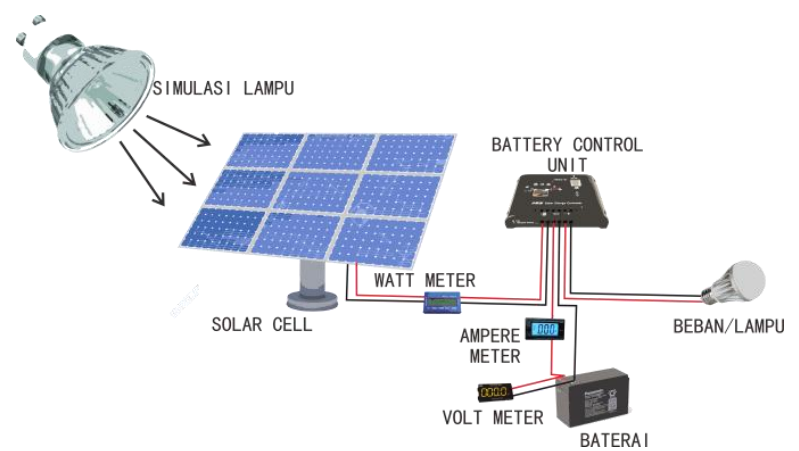

Gambar 4 Rangkaian pengujian panel surya vertikal dengan simulasi pencahayaan lampu.

Pengujian panel surya fleksibel dengan simulasi pencahayaan lampu dilakukan dengan menggunakan tiga sudut/benatuk. Diantaranya, bentuk $0^{\circ}$, cekung $25^{\circ}$, dan cembung $25^{\circ}$.

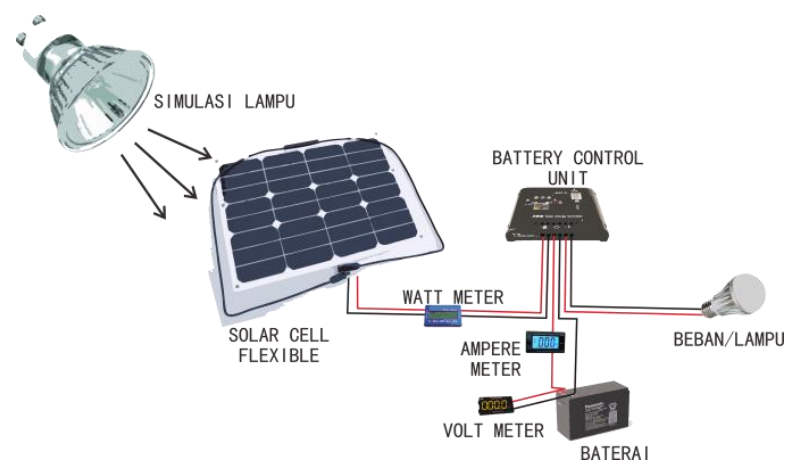

Gambar 5 Rangkaian pengujian panel surya fleksibel dengan simulasi pencahayaan lampu.

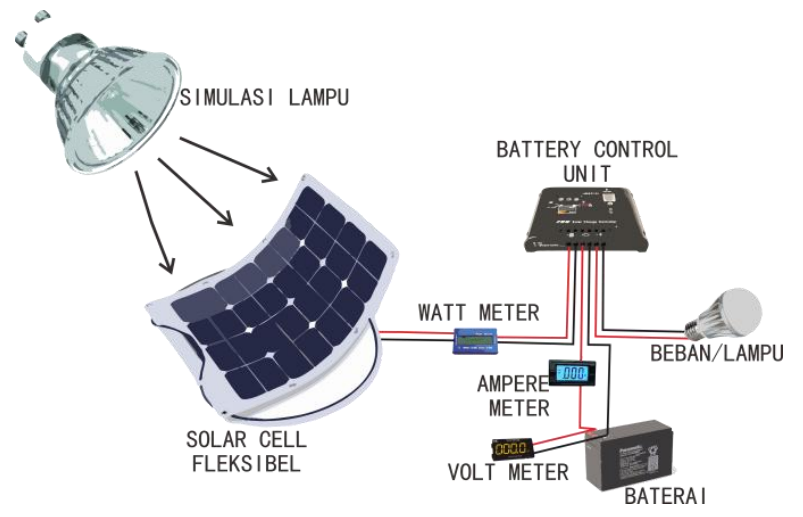

Gambar 6 Rangkaian pengujian panel surya fleksibel cekung $25^{\circ}$ dengan simulasi penyinaran lampu.

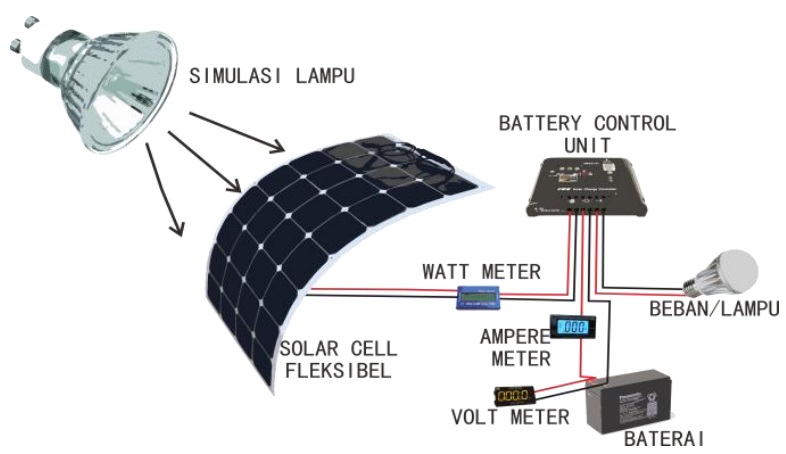

Gambar 7 Rangkaian pengujian panel surya fleksibel cembung $25^{\circ}$ dengan simulasi penyinaran lampu.

\section{HASIL DAN PEMBAHASAN}

Pada penelitian ini dirancang untuk dapat membandingkan kinerja panel surya vertikal dengan panel surya fleksibel jenis monocrystalline. Pada penelitian dengan menggunakan pencahayaan matahari dilakukan pada watu dan tempat yang bersamaan.

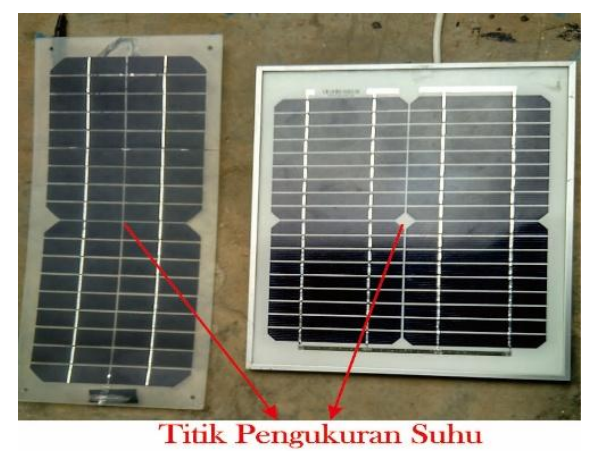

Gambar 8 Gambar pengujian panel surya dengan pencahayaan matahari.

Tabel 1 Hasil pengujian panel surya vertikal dengan pencahayaan matahari.

\begin{tabular}{|c|c|c|c|c|}
\hline Waktu & $\begin{array}{c}\text { Tegangan } \\
\text { Panel (V) }\end{array}$ & $\begin{array}{c}\text { Arus } \\
(\mathrm{A})\end{array}$ & $\begin{array}{c}\text { Daya } \\
(\mathrm{W})\end{array}$ & $\begin{array}{c}\text { Suhu } \\
\text { Panel } \\
\left({ }^{\circ} \mathrm{C}\right)\end{array}$ \\
\hline 09.00 .00 & 17,90 & 0,39 & 6,98 & 36,0 \\
\hline 09.30 .00 & 18,95 & 0,44 & 8,34 & 37,3 \\
\hline 10.00 .00 & 19,41 & 0,45 & 8,73 & 39,5 \\
\hline 10.30 .00 & 19,80 & 0,44 & 8,71 & 49,0 \\
\hline 11.00 .00 & 20,21 & 0,47 & 9,50 & 45,0 \\
\hline 11.30 .00 & 19,81 & 0,50 & 9,91 & 52,3 \\
\hline 12.00 .00 & 16,90 & 0,21 & 3,55 & 41,7 \\
\hline 12.30 .00 & 18,05 & 0,19 & 3,43 & 47,8 \\
\hline 13.00 .00 & 17,20 & 0,45 & 7,74 & 38,2 \\
\hline 13.30 .00 & 20,00 & 0,48 & 9,60 & 52,2 \\
\hline 14.00 .00 & 19,80 & 0,45 & 8,91 & 50,0 \\
\hline 14.30 .00 & 18,15 & 0,44 & 7,99 & 49,7 \\
\hline 15.00 .00 & 18,41 & 0,44 & 8,10 & 48,9 \\
\hline
\end{tabular}


RESISTOR (Elektronika Kendali Telekomunikasi Tenaga Listrik Komputer) Vol. 4 No. 1 e-ISSN : 2621-9700, p-ISSN : 2654-2684

\begin{tabular}{|c|c|c|c|c|}
15.30 .00 & 18,49 & 0,44 & 8,14 & 47,0 \\
\hline 16.00 .00 & 19,01 & 0,41 & 7,79 & 45,3 \\
\hline $\begin{array}{c}\text { Rata- } \\
\text { Rata }\end{array}$ & $\mathbf{1 8 , 4 6}$ & $\mathbf{0 , 4 0}$ & $\mathbf{7 , 3 9}$ & $\mathbf{4 0 , 7}$ \\
\hline
\end{tabular}

Dari tabel diatas di dapatkan efisiensi dengan perhitungan berikut :

$\eta$

$=\frac{P \max (\text { maximum power point })}{E \text { (incident radiation flix) } x \text { Ac (area of colect }}$

$\eta=\frac{9,91 W}{587 \frac{W}{m^{2}} \times(0,25 \times 0,35)} \times 100 \%$

$\eta=\frac{9,91}{51,3625} \times 100 \%$

$\eta=19,2844 \%$

Untuk melakukan perbandingan berikut hasil pengujian panel surya fleksibel dengan pencahayaan matahari.

Tabel 2 Hasil pengujian panel surya fleksibel dengan pencahayan matahari.

\begin{tabular}{|c|c|c|c|c|}
\hline Waktu & $\begin{array}{c}\text { Tegangan } \\
\text { Panel (V) }\end{array}$ & $\begin{array}{c}\text { Arus } \\
(\mathrm{A})\end{array}$ & $\begin{array}{c}\text { Daya } \\
(\mathrm{W})\end{array}$ & $\begin{array}{c}\text { Suhu } \\
\text { Panel } \\
\left({ }^{\circ} \mathrm{C}\right)\end{array}$ \\
\hline 09.00 .00 & 18,90 & 0,41 & 7,75 & 39,1 \\
\hline 09.30 .00 & 18,19 & 0,55 & 10,00 & 56,3 \\
\hline 10.00 .00 & 19,75 & 0,44 & 8,69 & 50,0 \\
\hline 10.30 .00 & 20,10 & 0,45 & 9,05 & 51,9 \\
\hline 11.00 .00 & 20,22 & 0,49 & 9,91 & 49,5 \\
\hline 11.30 .00 & 19,77 & 0,53 & 10,48 & 55,5 \\
\hline 12.00 .00 & 12,90 & 0,50 & 6,45 & 41,5 \\
\hline 12.30 .00 & 17,85 & 0,50 & 8,93 & 36,8 \\
\hline 13.00 .00 & 15,70 & 0,45 & 7,07 & 38,4 \\
\hline 13.30 .00 & 20,19 & 0,45 & 9,09 & 50,5 \\
\hline 14.00 .00 & 20,11 & 0,46 & 9,25 & 50,7 \\
\hline 14.30 .00 & 19,78 & 0,35 & 6,92 & 49,3 \\
\hline 15.00 .00 & 20,31 & 0,18 & 3,66 & 46,9 \\
\hline 15.30 .00 & 18,85 & 0,33 & 6,22 & 48,0 \\
\hline 16.00 .00 & 18,97 & 0,41 & 7,78 & 47,1 \\
\hline $\begin{array}{c}\text { Rata- } \\
\text { Rata }\end{array}$ & $\mathbf{1 8 , 9 4}$ & $\mathbf{0 , 4 1}$ & $\mathbf{7 , 7 6}$ & $\mathbf{4 3 , 1}$ \\
\hline
\end{tabular}

Dari hasil tabel pengujian panle surya fleksibel dengan pencahayaan matahari dapat dihitung efisiensi panel surya fleksibel dengan pencahayaan matahari sebagai berikut :

$\eta$

$$
\begin{aligned}
& =\frac{P \max (\text { maximum power point })}{E \text { (incident radiation flix) } \times \text { Ac (area of colector) }} \times 100 \% \\
& \eta=\frac{10,48 \mathrm{~W}}{587 \frac{W}{m^{2}} \times(0,19 \times 0,45)} \times 100 \% \\
& \eta=\frac{10,48}{50,1885} \times 100 \% \\
& \eta=20,8774 \%
\end{aligned}
$$

Agar memudahkan untuk melihat perbedaan dari hasil pengujian antara panel surya vertikal dengan panel surya fleksibel pada penyinaran matahari maka perbedaan itu digambarkan dalam bentuk grafik seperti pada dibawah ini.

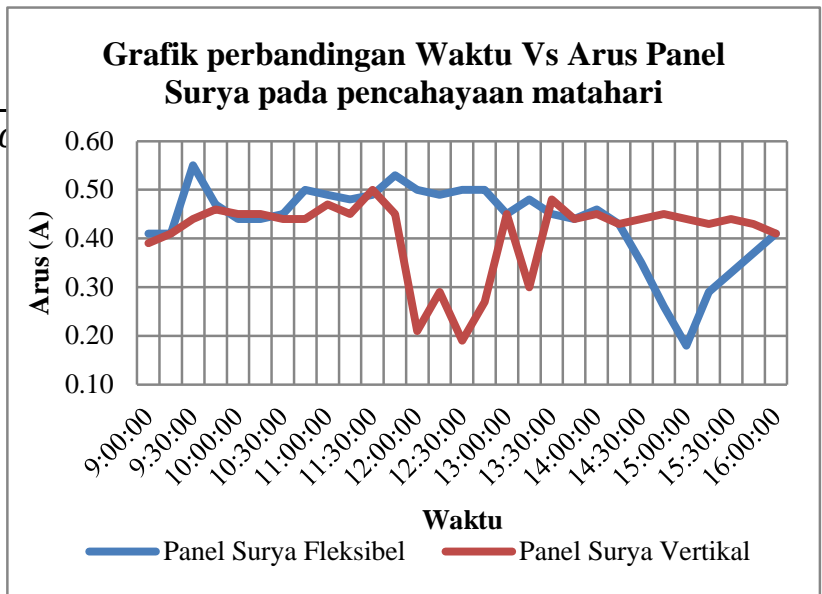

Gambar 9 Grafik perbedaan waktu vs arus panel surya vertikal dengan fleksibel pada pecahayaan matahari.

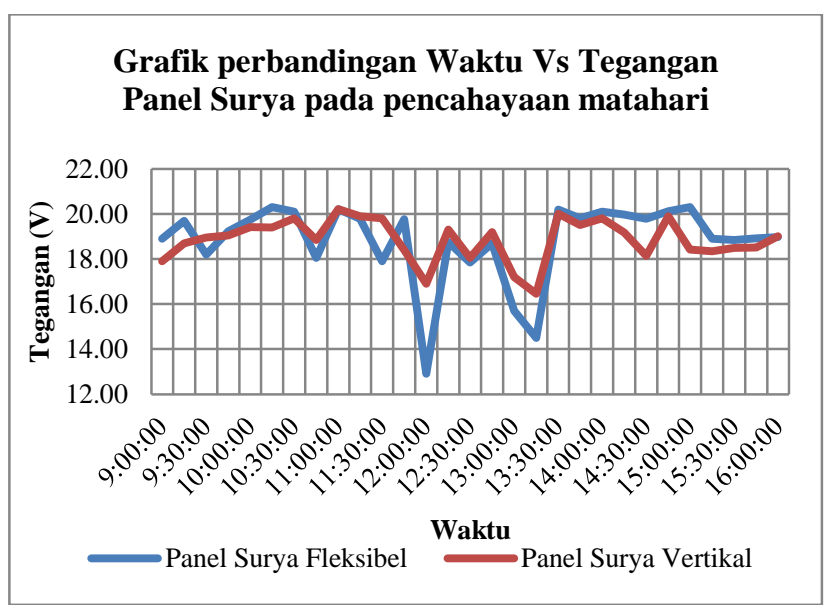

Gambar 10 Grafik perbedaan waktu vs tegangan panel surya vertikal dengan fleksibel pada pencahayaan matahari. 
RESISTOR (Elektronika Kendali Telekomunikasi Tenaga Listrik Komputer) Vol. 4 No. 1 e-ISSN : 2621-9700, p-ISSN : 2654-2684

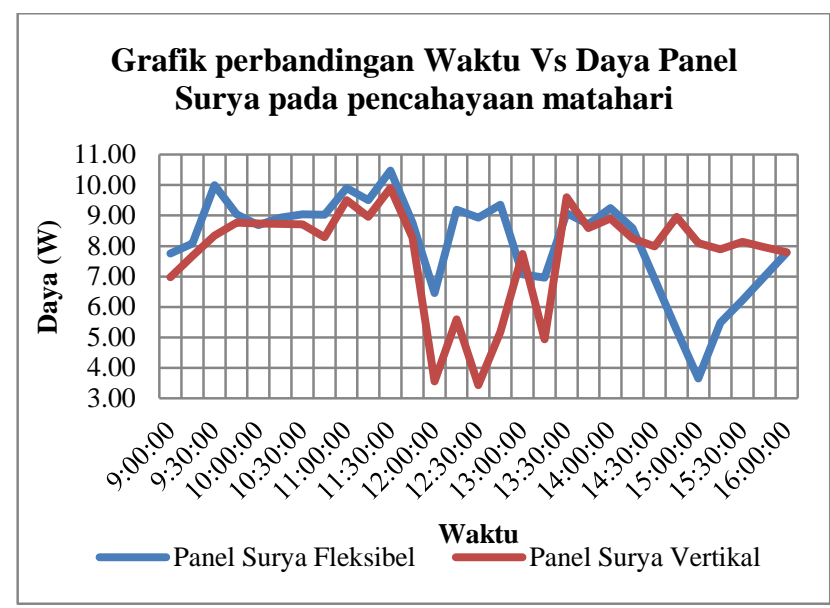

Gambar 11 Grafik perbedaan waktu vs daya panel surya vertikal dengan fleksibel pada pencahayaan matahari.

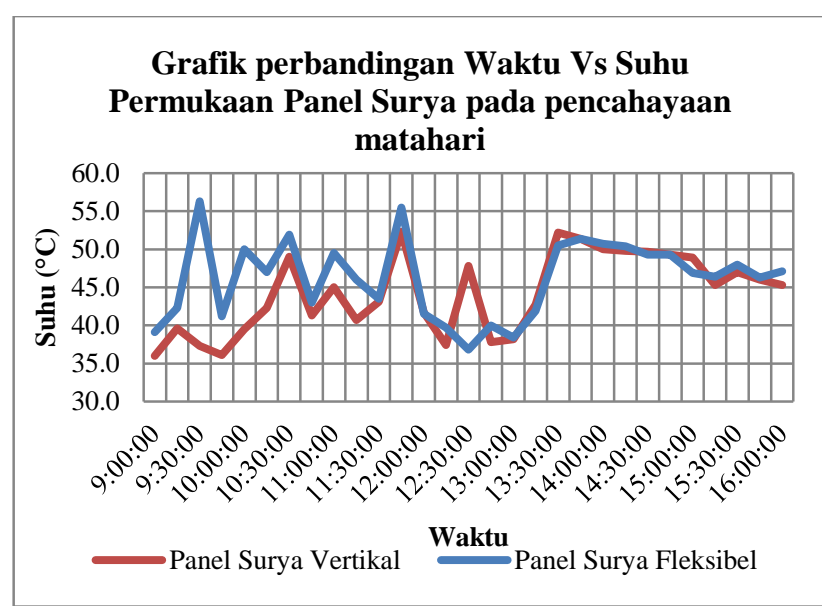

Gambar 12 Grafik perbedaan waktu vs suhu permukaan panel surya vertikal dengan fleksibel pada pencahayaan matahari.

Pengujian dengan simulasi pencahayaan lampu bertujuan untuk melihat kinerja panel surya pada kondisi dimana panas dan cahaya yang diterima oleh -panel surya konstan dengan waktu yang cukup lama. Pengujian dilakukan selama 8 jam dan dianalisa dengan jeda waktu setiap 15 menit.berdasarkan hasil pengukuran terhadap sumber pencahayaan, didapati bahwa intensitas cahaya yang didapat sebesar 760 $\mathrm{W} / \mathrm{m}^{2}$

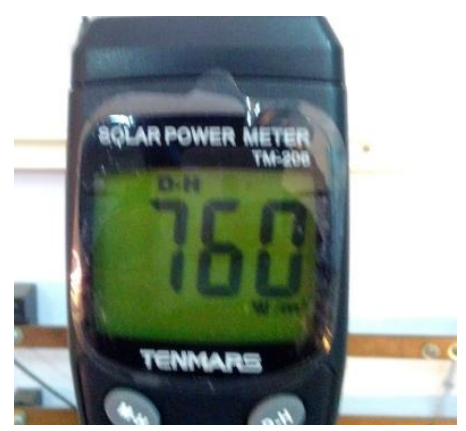

Gambar 13 Hasil pengukuran intensitas pencahayaan pada simulasi lampu.

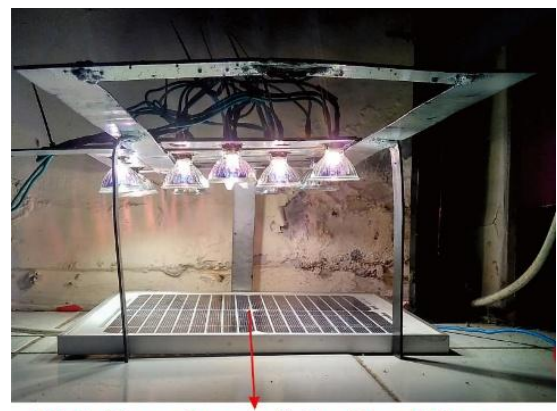

Titik Pengukuran Suhu Panel Surya

Gambar 14 Pengujian panel surya vertikal dengan simulasi pencahayaan lampu.

Tabel 3 Hasil pengujian panel surya vertikal dengan simulasi pencahayaan lampu.

\begin{tabular}{|c|c|c|c|c|}
\hline $\begin{array}{c}\text { Waktu } \\
\text { (Menit) }\end{array}$ & $\begin{array}{c}\text { Tegangan } \\
\text { Panel (V) }\end{array}$ & $\begin{array}{c}\text { Arus } \\
(\mathrm{A})\end{array}$ & $\begin{array}{c}\text { Daya } \\
(\mathrm{W})\end{array}$ & $\begin{array}{c}\text { Suhu } \\
\text { Panel } \\
\left({ }^{\circ} \mathrm{C}\right)\end{array}$ \\
\hline 0 & 20,03 & 0,68 & 13,62 & 31,3 \\
\hline 30 & 17,35 & 0,54 & 9,37 & 54,1 \\
\hline 60 & 17,09 & 0,50 & 8,55 & 60,3 \\
\hline 90 & 16,99 & 0,49 & 8,33 & 62,3 \\
\hline 120 & 16,87 & 0,48 & 8,10 & 64,1 \\
\hline 150 & 16,79 & 0,49 & 8,23 & 67,3 \\
\hline 180 & 16,57 & 0,48 & 7,95 & 68,7 \\
\hline 210 & 16,41 & 0,47 & 7,71 & 69,3 \\
\hline 240 & 16,93 & 0,45 & 7,62 & 70,2 \\
\hline 270 & 16,60 & 0,38 & 6,31 & 70,7 \\
\hline 300 & 16,41 & 0,25 & 4,10 & 70,7 \\
\hline 330 & 16,16 & 0,22 & 3,56 & 70,5 \\
\hline 360 & 16,55 & 0,21 & 3,48 & 71,2 \\
\hline 390 & 16,45 & 0,19 & 3,13 & 71,6 \\
\hline 420 & 16,36 & 0,19 & 3,11 & 72 \\
\hline 450 & 16,60 & 0,18 & 2,99 & 72,2 \\
\hline 480 & 16,82 & 0,18 & 3,03 & 72,1 \\
\hline $\begin{array}{c}\text { Rata- } \\
\text { Rata }\end{array}$ & $\mathbf{1 8 , 4 3}$ & $\mathbf{0 , 4 3}$ & $\mathbf{8 , 3 2}$ & $\mathbf{5 1 , 7}$ \\
\hline
\end{tabular}

Berdasarkan tabel hasil pengujian diatas yang terdapat daya output, tegangan, arus dan intensitas 
RESISTOR (Elektronika Kendali Telekomunikasi Tenaga Listrik Komputer) Vol. 4 No. 1 e-ISSN : 2621-9700, p-ISSN : 2654-2684

cahaya maka dapat dihitung efisiensi panel surya vertikal.

$\eta$

$=\frac{P \max (\operatorname{maximum} \text { power point })}{E \text { (incident radiation } f(i x) x \text { (area of } c 0}$

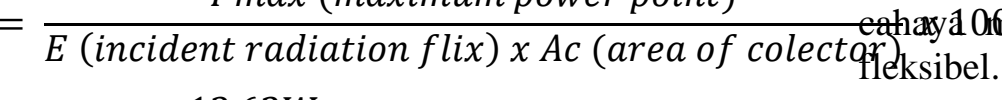

$\eta=\frac{13,62 W}{760 \frac{W}{m^{2}} \times(0,25 \times 0,35)} \times 100 \%$

$\eta=\frac{13,62}{66,5} \times 100 \%$

$\eta=20,4818 \%$

Untuk melakukan perbandingan berikut hasil

pengujian panel surya fleksibel dengan simulasi pencahayaan lampu.

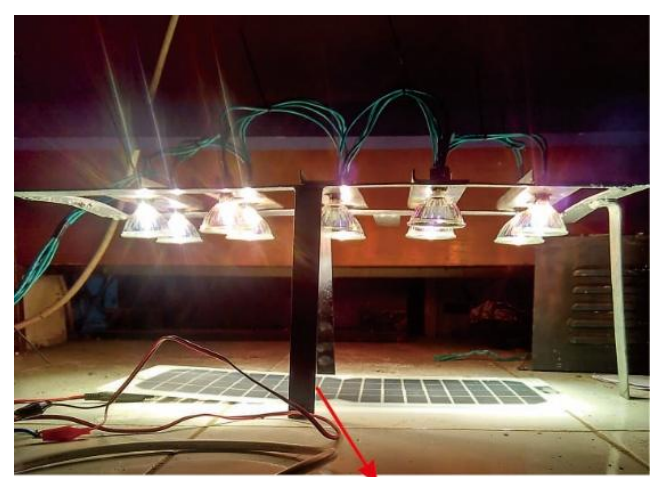

Titik Pengukuran Suhu

Gambar 15 Pengujian panel surya fleksibel bentuk $0^{\circ}$ dengan simulasi pencahayaan lampu.

Tabel 4 Hasil pengujian panel surya fleksibel bentuk $0^{\circ}$ dengan simulasi pencahayaan lampu

\begin{tabular}{|c|c|c|c|c|}
\hline $\begin{array}{c}\text { Waktu } \\
\text { (Menit) }\end{array}$ & $\begin{array}{c}\text { Tegangan } \\
\text { Panel (V) }\end{array}$ & $\begin{array}{c}\text { Arus } \\
(\mathrm{A})\end{array}$ & $\begin{array}{c}\text { Daya } \\
(\mathrm{W})\end{array}$ & $\begin{array}{c}\text { Suhu } \\
\text { Panel } \\
\left({ }^{\circ} \mathrm{C}\right)\end{array}$ \\
\hline 0 & 19,74 & 0,54 & 10,66 & 27,3 \\
\hline 30 & 18,96 & 0,50 & 9,48 & 47,1 \\
\hline 60 & 18,43 & 0,50 & 9,22 & 51,5 \\
\hline 90 & 18,55 & 0,48 & 8,90 & 52,9 \\
\hline 120 & 18,05 & 0,47 & 8,48 & 53,7 \\
\hline 150 & 18,16 & 0,45 & 8,17 & 54,9 \\
\hline 180 & 17,81 & 0,42 & 7,48 & 56,3 \\
\hline 210 & 18,06 & 0,35 & 6,32 & 56,3 \\
\hline 240 & 18,01 & 0,30 & 5,40 & 57,8 \\
\hline 270 & 18,11 & 0,28 & 5,07 & 57,5 \\
\hline 300 & 17,99 & 0,28 & 5,04 & 59,3 \\
\hline 330 & 17,95 & 0,26 & 4,67 & 60,2 \\
\hline 360 & 17,90 & 0,28 & 5,01 & 59,8 \\
\hline 390 & 17,35 & 0,28 & 4,86 & 57,8 \\
\hline 420 & 17,88 & 0,29 & 5,19 & 57,7 \\
\hline 450 & 17,55 & 0,28 & 4,91 & 61,0 \\
\hline
\end{tabular}

\begin{tabular}{|c|c|c|c|c|}
480 & 17,66 & 0,29 & 5,12 & 60,5 \\
\hline $\begin{array}{c}\text { Rata - } \\
\text { Rata }\end{array}$ & $\mathbf{1 8 , 7 0}$ & $\mathbf{0 , 4 2}$ & $\mathbf{7 , 8 9}$ & $\mathbf{4 3 , 9}$ \\
\hline
\end{tabular}

Berdasarkan tabel hasil pengujian diatas yang terdapat daya output, tegangan, arus dan intensitas aranaka dapat dihitung efisiensi panel surya

$\eta$

$=\frac{P \max (\text { maximum power point })}{E \text { (incident radiation flix) } \times \text { Ac (area of colector })} \times 100$

$\eta=\frac{10,66 W}{760 \frac{W}{m^{2}} \times(0,19 \times 0,45)} \times 100 \%$

$\eta=\frac{10,66}{64,98} \times 100 \%$

$\eta=16,4044 \%$

Dibawah ini terdapar grafik yang membedakan keluaran panel surya vertikal dan panel surya fleksibel pada simulasi pencahayaan lampu.

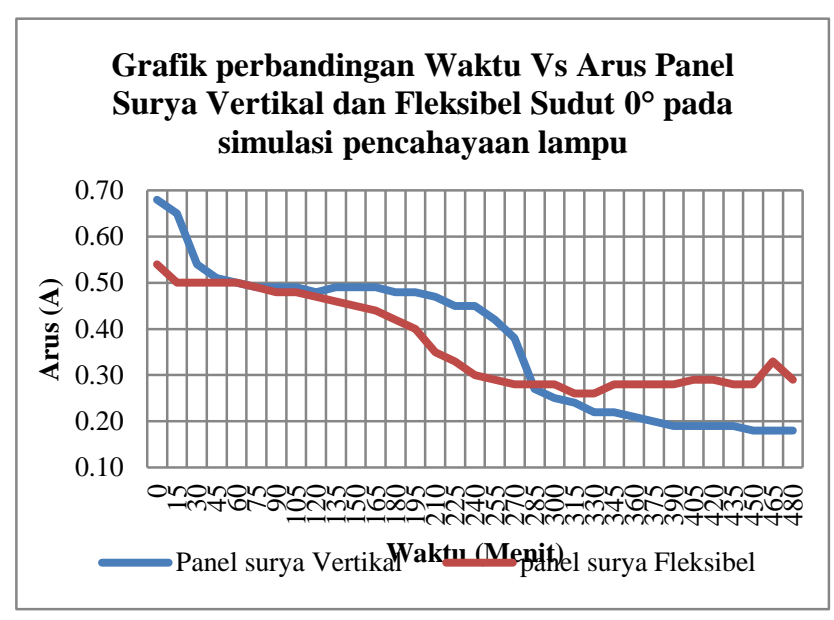

Gambar 16 Grafik perbedaan waktu vs Arus panel surya vertikal dengan fleksibel bentuk datar $0^{\circ}$ pada simulasi pencahayaan lampu. 
RESISTOR (Elektronika Kendali Telekomunikasi Tenaga Listrik Komputer) Vol. 4 No. 1 e-ISSN : 2621-9700, p-ISSN : 2654-2684

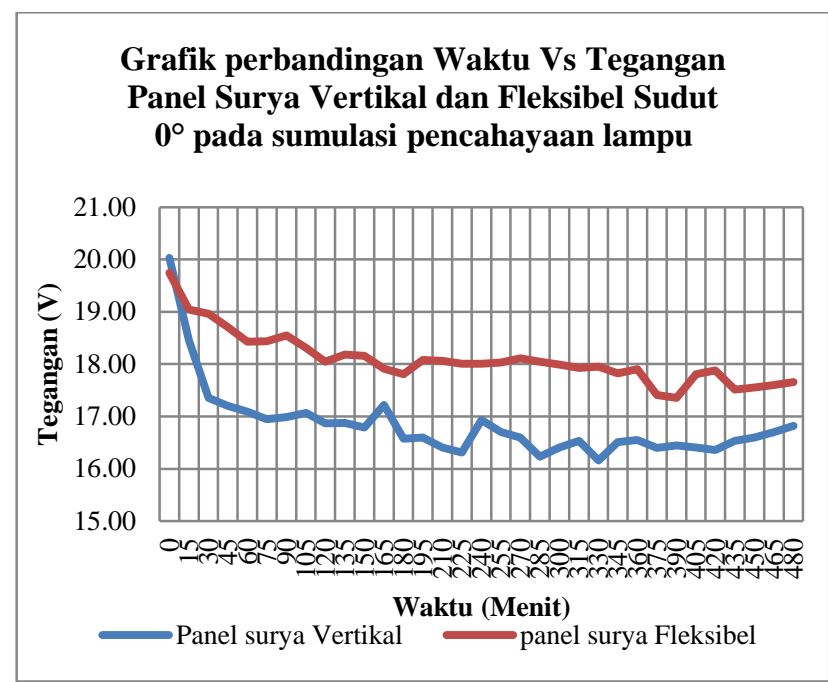

Gambar 17 Grafik perbedaan waktu vs Tegangan panel surya vertikal dengan fleksibel bentuk datar $0^{\circ}$ pada simulasi pencahayaan lampu.

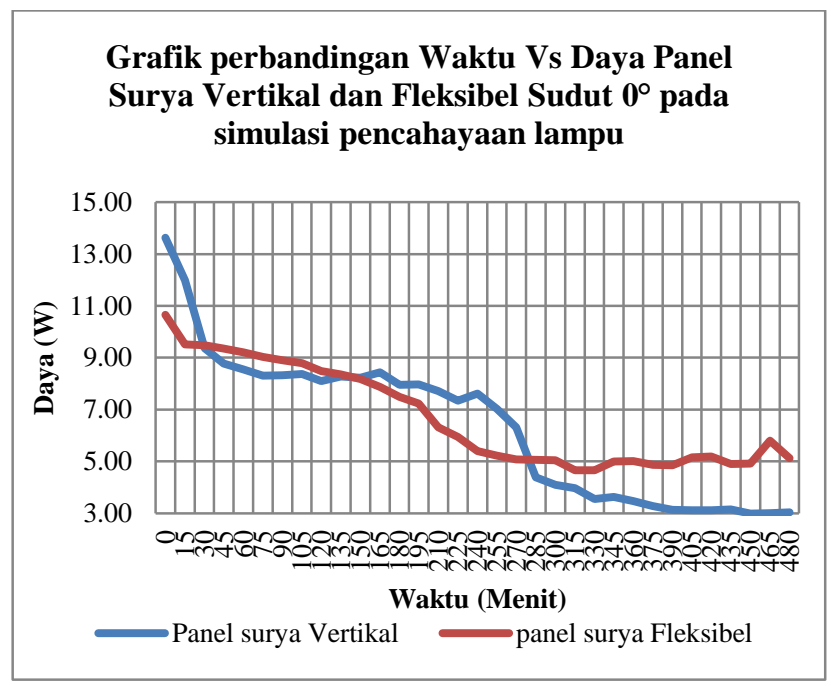

Gambar 18 Grafik perbedaan waktu vs Daya panel surya vertikal dengan fleksibel bentuk datar $0^{\circ}$ pada simulasi pencahayaan lampu.

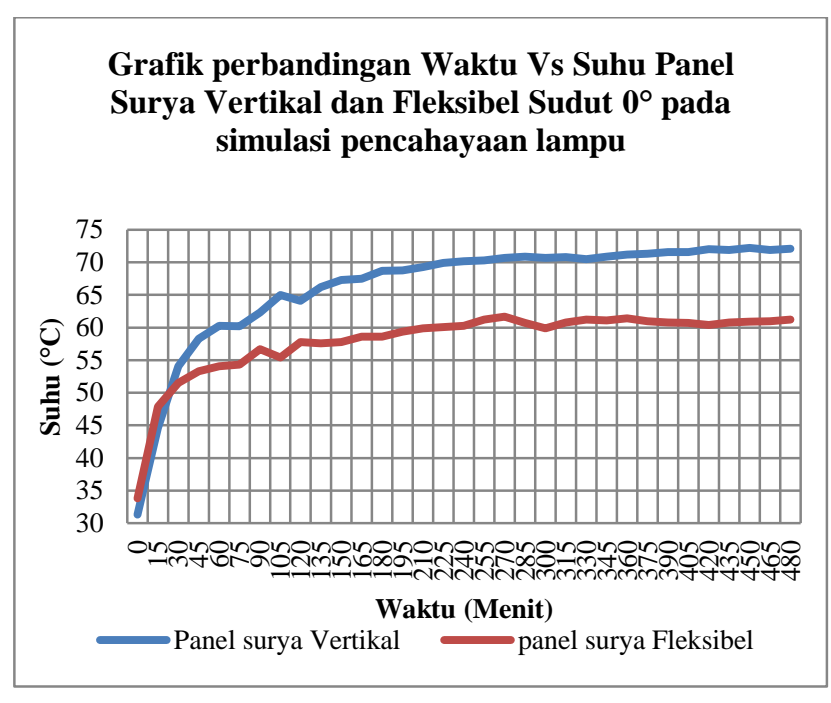

Gambar 19 Grafik perbedaan waktu vs suhu panel surya vertikal dengan fleksibel bentuk datar $0^{\circ}$ pada simulasi pencahayaan lampu.

Pengujian panel surya fleksibel dengan keadaan cembung $25^{\circ}$ dilakukan dengan simulasi pencahayaan lampu.

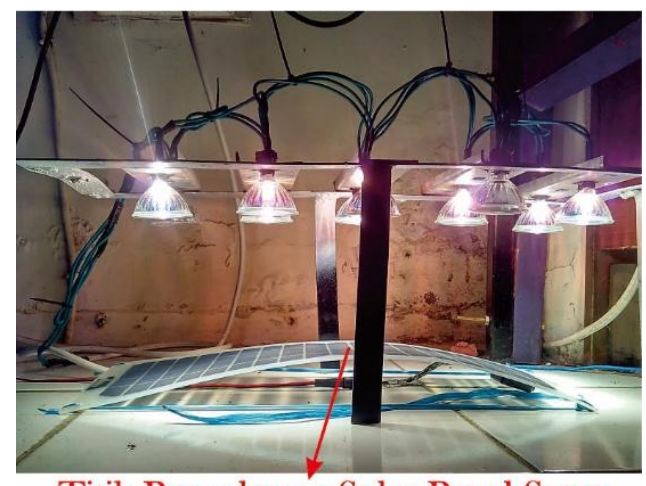

Titik Pengukuran Suhu Panel Surya

Gambar 20 Pengujian panel surya fleksibel bentuk cembung $25^{\circ}$ dengan simulasi pencahayaan lampu.

Tabel 5 Pengujian panel surya fleksibel cembung $25^{\circ}$ dengan simulasi pencahayaan lampu.

\begin{tabular}{|c|c|c|c|c|}
\hline $\begin{array}{c}\text { Waktu } \\
(\text { Menit })\end{array}$ & $\begin{array}{c}\text { Tegangan } \\
\text { Panel (V) }\end{array}$ & $\begin{array}{c}\text { Arus } \\
(\mathrm{A})\end{array}$ & $\begin{array}{c}\text { Daya } \\
(\mathrm{W})\end{array}$ & $\begin{array}{c}\text { Suhu } \\
\text { Panel } \\
\left({ }^{\circ} \mathrm{C}\right)\end{array}$ \\
\hline 0 & 19,91 & 0,50 & 9,96 & 33,8 \\
\hline 30 & 18,80 & 0,50 & 9,40 & 51,5 \\
\hline 60 & 17,75 & 0,50 & 8,88 & 54,1 \\
\hline 90 & 17,96 & 0,49 & 8,80 & 56,7 \\
\hline 120 & 17,39 & 0,48 & 8,35 & 57,8 \\
\hline 150 & 17,20 & 0,30 & 5,16 & 57,8 \\
\hline 180 & 17,10 & 0,25 & 4,28 & 58,6 \\
\hline
\end{tabular}


RESISTOR (Elektronika Kendali Telekomunikasi Tenaga Listrik Komputer) Vol. 4 No. 1 e-ISSN : 2621-9700, p-ISSN : 2654-2684

\begin{tabular}{|c|c|c|c|c|}
210 & 17,40 & 0,24 & 4,18 & 59,9 \\
\hline 240 & 17,37 & 0,23 & 4,00 & 60,3 \\
\hline 270 & 17,25 & 0,23 & 3,97 & 61,7 \\
\hline 300 & 17,41 & 0,22 & 3,83 & 59,9 \\
\hline 330 & 17,24 & 0,22 & 3,79 & 61,2 \\
\hline 360 & 17,21 & 0,24 & 4,13 & 61,4 \\
\hline 390 & 17,18 & 0,24 & 4,12 & 60,8 \\
\hline 420 & 17,29 & 0,24 & 4,15 & 60,4 \\
\hline 450 & 17,48 & 0,24 & 4,20 & 60,9 \\
\hline 480 & 17,45 & 0,24 & 4,19 & 61,2 \\
\hline $\begin{array}{c}\text { Rata- } \\
\text { Rata }\end{array}$ & $\mathbf{1 8 , 6 8}$ & $\mathbf{0 , 3 7}$ & $\mathbf{7 , 0 7}$ & $\mathbf{4 7 , 5}$ \\
\hline
\end{tabular}

Dari hasil pengujian panel surya fleksibel dengan keadaan cembung $25^{\circ}$ dapat dihitung efisiensi kinerjanya dengan perhitungan berikut :

$\eta$ $=\frac{P \max (\text { maximum power point) }}{E \text { (incident radiation flix) } \times \text { Ac (area of colector })}$

\begin{tabular}{|c|c|c|c|c|}
30 & 18,05 & 0,46 & 8,30 & 52,4 \\
\hline 60 & 17,44 & 0,28 & 4,88 & 54,4 \\
\hline 90 & 17,89 & 0,27 & 4,83 & 56,2 \\
\hline 120 & 17,83 & 0,26 & 4,64 & 56,4 \\
\hline 150 & 17,78 & 0,26 & 4,62 & 58,4 \\
\hline 180 & 17,68 & 0,26 & 4,60 & 58,9 \\
\hline 210 & 17,71 & 0,26 & 4,60 & 59,7 \\
\hline 240 & 17,50 & 0,28 & 4,90 & 60,1 \\
\hline 270 & 17,55 & 0,28 & 4,91 & 60,1 \\
\hline 300 & 17,49 & 0,28 & 4,90 & 60,6 \\
\hline 330 & 17,70 & 0,27 & 4,78 & 59,9 \\
\hline 360 & 17,67 & 0,28 & 4,95 & 60,7 \\
\hline 390 & 17,35 & 0,26 & 4,51 & 60,7 \\
\hline 420 & 17,61 & 0,26 & 4,58 & 60,9 \\
\hline 450 & 17,40 & 0,27 & 4,70 & 61,3 \\
\hline 480 & 17,48 & 0,27 & 4,72 & 61,7 \\
\hline $\begin{array}{c}\text { Rata- } \\
\text { Rata }\end{array}$ & $\mathbf{1 8 , 7 0}$ & $\mathbf{0 , 3 9}$ & $\mathbf{7 , 4 4}$ & $\mathbf{4 6 , 9}$ \\
\hline
\end{tabular}
$\eta=\frac{9,96 W}{760 \frac{W}{m^{2}} \times(0,19 \times 0,45)} \times 100 \%$

$\eta=\frac{9,96}{64,98} \times 100 \%$

$\eta=15,3200 \%$

Pengujian panel surya fleksibel dengan keadaan cekung $25^{\circ}$ dilakukan dengan simulasi pencahayaan lampu

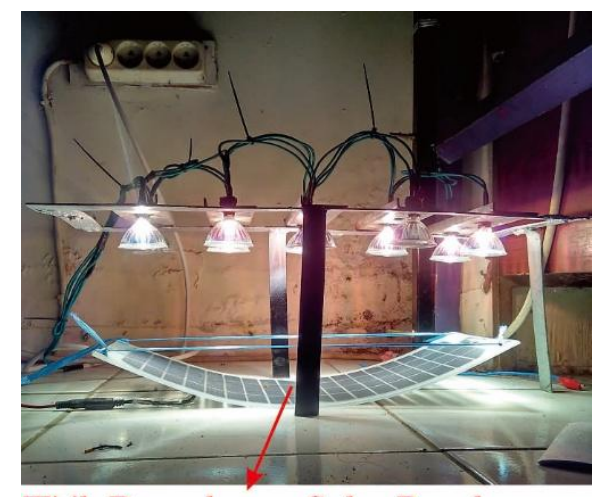

Titik Pengukuran Suhu Panel

Gambar 21 Pengujian panel surya fleksibel bentuk cekung $25^{\circ}$ dengan simulasi pencahayaan lampu

Tabel 6 Hasil pengujian panel surya fleksibel cekung $25^{\circ}$ dengan simulasi pencahayaan lampu.

\begin{tabular}{|c|c|c|c|c|}
\hline $\begin{array}{c}\text { Waktu } \\
\text { (Menit) }\end{array}$ & $\begin{array}{c}\text { Tegangan } \\
\text { Panel (V) }\end{array}$ & $\begin{array}{c}\text { Arus } \\
(\mathrm{A})\end{array}$ & $\begin{array}{c}\text { Daya } \\
(\mathrm{W})\end{array}$ & $\begin{array}{c}\text { Suhu } \\
\text { Panel } \\
\left({ }^{\circ} \mathrm{C}\right)\end{array}$ \\
\hline 0 & 19,91 & 0,51 & 10,15 & 32,1 \\
\hline
\end{tabular}

dengan keadaan cekung $25^{\circ}$ dapat dihitung efisiensi kinerjanya dengan perhitungan berikut :

$\eta$

$$
=\frac{P \max (\text { maximum power point })}{E \text { (incident radiation flix }) \times \text { Ac (area of colector })} \times 100
$$$$
\eta=\frac{10,15 W}{760 \frac{W}{m^{2}} \times(0,19 \times 0,45)} \times 100 \%
$$

$\eta=\frac{10,15}{64,98} \times 100 \%$

$\eta=15,6265 \%$

Dibawah ini terdapar grafik yang membedakan keluaran panel surya vertikal dan panel surya fleksibel pada simulasi pencahayaan lampu.

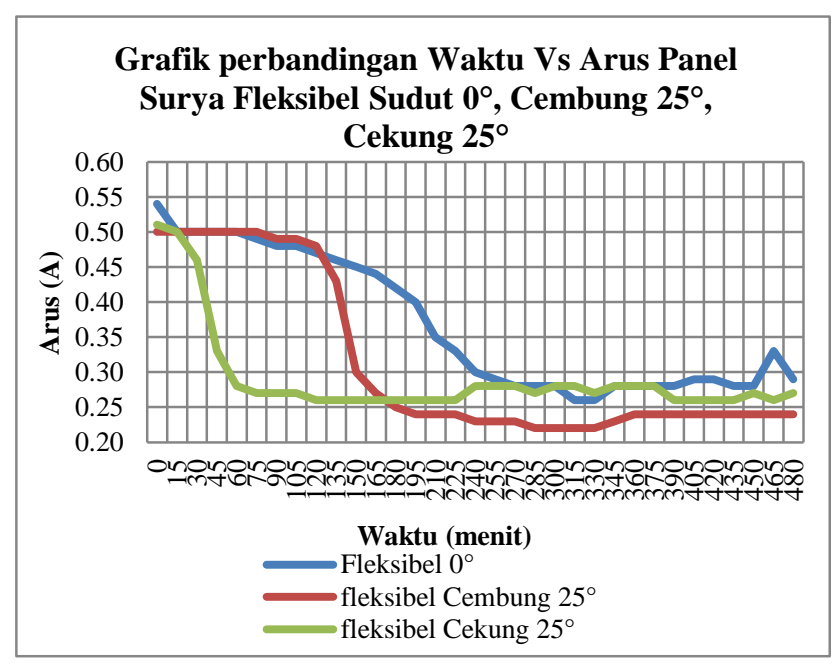

Gambar 22 Grafik perbedaan waktu vs arus panel surya fleksibel bentuk datar $0^{\circ}$, cembung $25^{\circ}$ 
RESISTOR (Elektronika Kendali Telekomunikasi Tenaga Listrik Komputer) Vol. 4 No. 1 e-ISSN : 2621-9700, p-ISSN : 2654-2684

dan cekung $25^{\circ}$ pada simulasi pencahayaan lampu

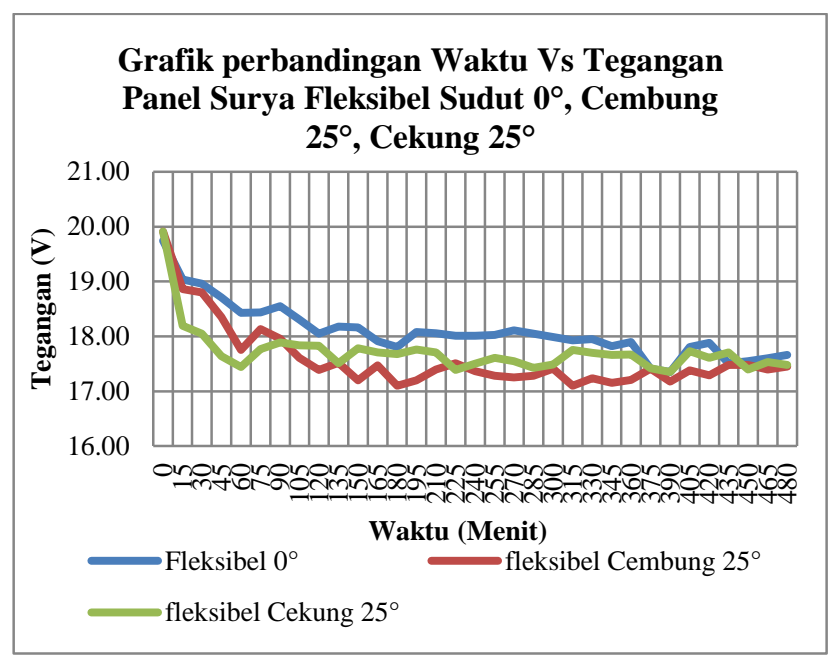

Gambar 23 Grafik perbedaan waktu vs tegangan panel surya fleksibel bentuk datar $0^{\circ}$, cembung $25^{\circ}$, dan cekung $25^{\circ}$ pada simulasi pencahayaan lampu

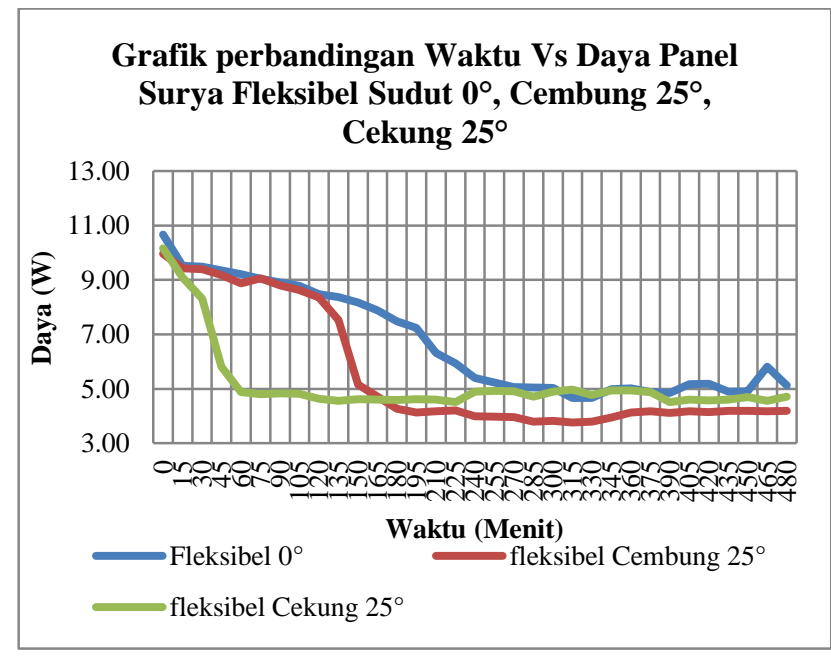

Gambar 24 Grafik perbedaan waktu vs daya panel surya fleksibel bentuk datar $0^{\circ}$, cembung $25^{\circ}$, dan cekung $25^{\circ}$ pada simulasi pencahyaan lampu.

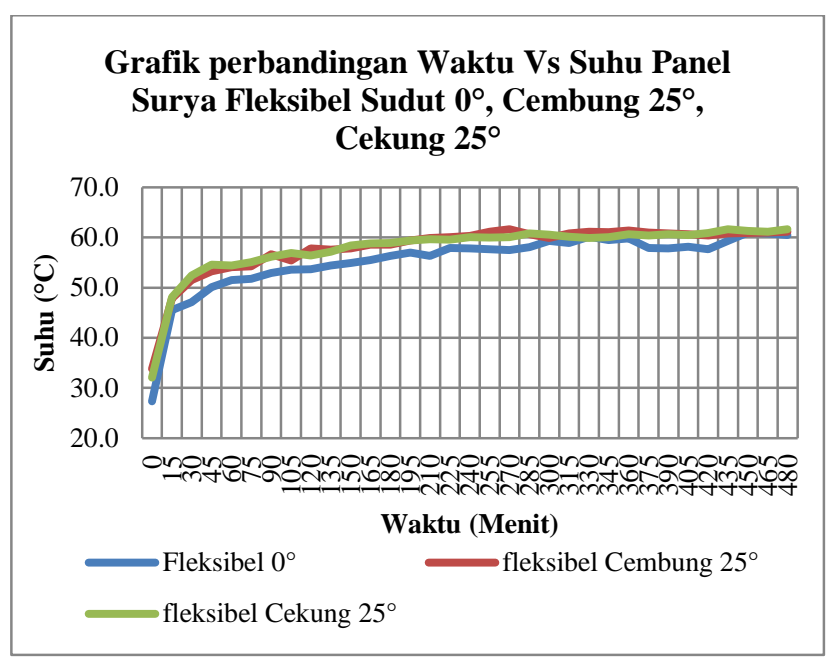

Gambar 25 Grafik perbedaan waktu vs suhu panel surya fleksibel bentuk datar $0^{\circ}$, cembung $25^{\circ}$, dan cekung $25^{\circ}$ pada simulasi pencahayaan lampu.

\section{KESIMPULAN}

Dari hasil pengujian dan analisa pada saat pencahayaan matahari panel surya monocrystalline jenis fleksibel menghasilkan output yang lebih tinggi dibandingkan dengan panel surya vertikal. Output tersebut meliputi rata-rata tegangan, arus, daya dan efisiensi. Dari hasil pengujian dan analisa dengan simulasi pencahayaan lampu panel surya mococrystalline jenis fleksibel menghasilkan rata rata tegangan lebih tinggi dibanding panel surya vertikal. Tetapi, pada arus, daya, dan efisiensi panel surya vertikal menghasilkan output yang lebih baik dibanding dengan panel surya fleksibel. Dari hasil pengujian dan analisa dengan simulasi pencahayaan lampu panel surya fleksibel dengan bentuk $0^{\circ}$, cembung $25^{\circ}$, cekung $25^{\circ}$ menghasilkan output yang berbeda - beda diantara bentuk tersebut. Panel surya fleksibel bentuk $0^{\circ}$ menghasilkan output tegangan, arus, daya, dan efisiensi yang lebih baik diantara bentuk lainnya.

\section{DAFTAR PUSTAKA}

[1] T. Damas Setyo, "Rancang Bangun Sistem Penangkapan Energi Maksimum Pada Solar Cell," Universitas Indonesia, 2009.

[2] F. Z. Ardhi, "Rancang Bangun Charge Controller Pembangkit Listrik Tenaga Surya," Universitas Indonesia, 2011.

[3] W. Diputra, "Simulator algoritma pendeteksi kerusakan modul surya pada rangkaian modul surya," 2008. 
RESISTOR (Elektronika Kendali Telekomunikasi Tenaga Listrik Komputer) Vol. 4 No. 1 e-ISSN : 2621-9700, p-ISSN : 2654-2684

[4] J. L. Cruz-Campa et al., "Ultrathin flexible crystalline silicon: Microsystems-enabled photovoltaics," IEEE journal of Photovoltaics, vol. 1, no. 1, pp. 3-8, 2011.

[5] A. Julisman, I. D. Sara, and R. H. Siregar, "Prototipe Pemanfaatan Panel Surya Sebagai Sumber Energi Pada Sistem Otomasi Stadion Bola," Jurnal Karya Ilmiah Teknik Elektro, vol. 2, no. 1, 2017.

[6] K. Trautz et al., "High efficiency flexible solar panels," in 2013 IEEE 39th Photovoltaic Specialists Conference (PVSC), 2013, pp. 0115-0119.

[7] M. Pagliaro, R. Ciriminna, and G. Palmisano, "Flexible solar cells," ChemSusChem: Chemistry \& Sustainability Energy \& Materials, vol. 1, no. 11, pp. 880-891, 2008.

[8] K.-H. Tsai et al., "High efficiency of flexible polymer solar cell based on poly (3hexylthiophene)/fullerene," in 2009 34th IEEE Photovoltaic Specialists Conference (PVSC), 2009, pp. 001678-001680.

[9] S. R. Wenham, Applied photovoltaics. Routledge, 2011.

[10] D. L. Pangestuningtyas, H. Hermawan, and K. Karnoto, "Analisis pengaruh sudut kemiringan panel surya terhadap radiasi matahari yang diterima oleh panel surya tipe larik tetap," Transient: Jurnal Ilmiah Teknik Elektro, vol. 2, no. 4, pp. 930-937, 2014. 